\title{
ВІДТОЧУЮЧИ МОВНУ МАЙСТЕРНІСТЬ (Українська мова (за професійним спрямуванням) : підручник / О. С. Черемська, В. Г. Сухенко. - Харків : ХНЕУ ім. С. Кузнеця, 2018. - 436 с.)
}

Кожна молода людина сьогодні прагне здобути професійну кваліфікацію, яка сприятиме іiі успішному зростанню. Основним щаблем (і найнижчим - і найвищим) в осягненні цієї мети є мовна майстерність. Педагогічна практика має низку методів, прийомів, форм для розвитку особистості через удосконалення іiі мовної діяльності. Гуманітарне спрямування вищої школи передбачає створення відповідних умов для саморозвитку мовної особистості та реалізації компетентнісного підходу.

Здобутки сучасної лінгводидактики (принцип універсалізму мови, іiі роль у нерозривних процесах пізнання й виховання, формуванні комунікативної спроможності, творчої активності, україноцентризму) намагалися взяти за основу автори рецензованого підручника «Українська мова (за професійним спрямуванням)». Таке підгрунтя створює міцну основу для гармонійного розвитку мовної особистості в контексті засвоєння загальнолюдських цінностей.

Прагнучи реалізувати потребу фахової підготовки студентів, основаної на професійній, інформаційній, лінгвістичній, комунікативній компетенціях, О. С. Черемська, В. Г. Сухенко упродовж десятиріччя здійснювали роботу із забезпечення компетентнісного підходу, зокрема підготували низку навчально-методичних праць, апробованих у практиці викладання «Української мови (за професійним спрямуванням)» у Харківському національному економічному університеті імені Семена Кузнеця, що передували створенню підручника.

Структура видання повністю відповідає структурі навчальної дисципліни та ії програмі. Підручник «Українська мова (за професійним спрямуванням)» складається з двох розділів, що охоплюють десять змістових тем, вступу та додатків, покликаних оптимізувати навчальну діяльність. Така структура рецензованого видання мотивована й дає змогу забезпечити теоретичні й практичні аспекти мовної освіти у професійних сферах комунікації.

Вступна частина містить опис мети й завдань підручника 3 покликанням на сентенції й академічні підходи щодо значення мови в житті особистості, зокрема С. Я. Єрмоленко та І. Р. Вихованця; обгрунтування структурних компонентів, рекомендації до застосування системи позначок засобів візуалізації (с. 3-4).

Автори підручника ставили за мету спрямувати учасників навчального процесу до вивчення української літературної мови у двох аспектах: нормативному та стилістичному, - випробуваних практикою викладання 
навчальної дисципліни «Українська мова (за професійним спрямуванням)» у вищій школі. Здійснення цієї мети можливе за умови грунтовного оволодіння нормами сучасної української літературної мови, ознайомлення із жанровими різновидами функціональних стилів, основами красномовства, а також активізації та набуття знань сучасної професійної комунікації, що $є$ сьогодні на часі.

Змістове наповнення підручника охоплює широке коло важливих мовних тем, що висвітлюють загальнотеоретичні відомості про мову, значення мови в суспільстві, функції мови, норми та функціональні стилі, а також історію формування української літературної мови. Особливу увагу зосереджено на професійному, науковому та офіційно-діловому аспектах комунікації.

Перший розділ «Нормативність як основа літературної мови» містить п'ять змістових тем, які присвячені розгляду нормативних аспектів сучасної української літературної мови. Підгрунтям аналізу теоретичних проблем стали наукові підходи Б. Д. Антоненка-Давидовича, Н. Д. Бабич, О. Г. Муромцевої, Л. В. Струганець та ін. У першій темі «Комунікативна компетентність у професійній діяльності мовної особистості. Історія походження та розвитку української літературної мови. Українська мова серед інших мов світу» акцентовано на мові як суспільному явищі, розкрито форми існування та функції мови. Увагу привертає грунтовний аналіз становлення й історичного розвитку літературної мови та ії сучасного стану з опертям на дослідження Ю. О. Жлуктенка, Л. Т. Масенко, О. Г. Муромцевої, І. Огієнка, В. М. Русанівського та ін.

Подальші теми першого розділу «Нормативність як важлива ознака літературної мови. Типи мовних норм. Орфоепічні та акцентуаційні норми української літературної мови», «Лексичний склад української літературної мови. Лексична норма як компонент формування мовної компетенції», «Морфологічні та орфографічні норми як чинник належного рівня культури мови», «Синтаксичні та пунктуаційні норми як компонент формування мовної компетенцї̈» спрямовані на формування культури мови особистості, розвитку мовного чуття й мовної майстерності. Грунтовно описано норми української орфоепії й акцентуації, систематизовано лексичний матеріал із широким залученням професійного й термінологічного тезаурусів; у зіставному аспекті представлено граматичні норми в поєднанні з орфографією, що й забезпечує системний підхід до вивчення української літературної мови в професійному аспекті.

У другому розділі «Культура усної та писемної мови в стильових різновидах» представлено п'ять змістових тем, присвячених функціональній стилістиці та красномовству, що спрямовані на формування стилістичної вправності та мовного чуття студентів із залученням системи теоретичних відомостей та практичних завдань. Теоретичний матеріал розділу, зокрема теми «Художня література як основа формування культури мови особистос$m i »$, відображає аспекти естетичного впливу художнього слова на розвиток 
мови особистості. Його побудова в такій перспективі є суголосною 3 навчально-виховною концепцією викладання української (державної) мови (С. Я. Єрмоленко, Л. І. Мацько, О. Г. Муромцевої) та уможливлює забезпечення професійної компетентності й грамотності студентів і $є$ важливим підгрунтям у досягненні відповідного рівня фахових знань.

Актуальним $є$ аспект висвітлення історії української літературної мови крізь призму творчості І. П. Котляревського, Г. Ф. Квітки-Основ'яненка, П. О. Куліша, Т. Г. Шевченка, Марка Вовчка, Лесі Українки та ідіостилю сучасних українських майстрів слова.

Схвалення заслуговують інформаційно насичені теоретичні відомості про характерні риси та мовні засоби, жанрову своєрідність наукового та офіційно-ділового стилів, систематизовані й представлені в таблицях і схемах, уведення яких спрямоване на максимальне розкриття авторського задуму.

Добір джерел, на які покликаються автори, дає змогу читачеві створити чітке уявлення про місце української мови в науковому та суспільному житті, про ії включеність у різноманітні наукові дискурси, сприяє відчуттю об’єктивності представленої картини.

Із метою активізації сприйняття й актуалізації теоретичної інформації застосовано сучасні засоби представлення навчального матеріалу: схеми, картосхеми, таблиці та інші види інформаційної графіки. До кожної теми запропоновано цікаві рубрики, рекомендовану літературу, запитання й завдання для самодіагностики, практичні завдання та різнопланові тести для самоконтролю, що дають змогу оцінити рівень здобутих знань і сформованих компетенцій. 3 урахуванням аспектів лінгводидактики запропоновано систему творчих вправ, винесених у рубрику «Домашнє завдання», які сприятимуть розвитку вмінь і навичок як усного, так і писемного мовлення студентів, що є важливою умовою повноцінного опанування мови.

Перевагою підручника $є$ також інформативно насичені й корисні додатки, уміщені наприкінці кожної частини видання, які доповнюють відповідні розділи та сприяють формуванню лінгвістичної, мовленнєвої й комунікативної компетенцій у науковому спілкуванні, що інтегрує національний, культурний та психологічний компоненти. Так, у першому розділі «Нормативність як основа літературної мови» додано російсько-український міні-словник найбільш уживаних слів та сталих словосполучень економічної термінології (с. 191-206); складні випадки українського літературного слововживання (с. 207-211); словник найуживаніших фразеологізмів (с. 212216); таблицю «Пишімо й говорімо правильно» (с. 217-218) та іменники на позначення осіб чоловічої та жіночої статі за національністю чи територіальною ознакою (с. 219-220). У додатках другого розділу «Культура усної та писемної мови в її стильових різновидах» уміщено рубрику «Лінгвістичні етюди» (мовознавчі вірші Дмитра Білоуса) (с. 399-412); вимоги до написання есе (c. 413); схему стилістичного аналізу тексту (с. 114-415) та зразки оформлення документів (с. 416-430). 
Підручник «Українська мова (за професійним спрямуванням)» авторів О. С. Черемської, В. Г. Сухенко є відгуком на потреби сучасної мовної освіти. Оригінальне видання, яке має наукову новизну та практичну цінність, буде корисним для науковців, викладачів української мови, аспірантів, студентів, які навчаються як в економічних вишах, так і в інших закладах вищої освіти.

Голобородько Костянтин Юрійович - доктор філологічних наук, професор, декан українського мовно-літературного факультету ім. Г.Квітки-Основ'яненка, Харківський національний педагогічний університет імені Г. С. Сковороди; вул. Валентинівська, 2, Харків, 61168, Україна.

Tel.: +38 0679388667

E-mail: konceptikos@gmail.com

https://orcid.org/0000-0001-6004-4003

Holoborodko Kostiantyn Yuriiovych - Doctor of Philology, Professor, Dean of the Ukrainian Language and Literature Faculty named after H. Kvitka-Osnovianenko, H. S. Skovoroda Kharkiv National Pedagogical University; Valentynivska Str., 2, Kharkiv, 61168, Ukraine.

Надійшла до редакції 11 квітня 2019 року 